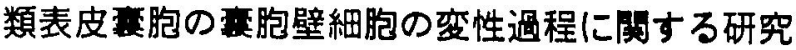

梁川哲雄・佐藤光们・白砂非光・啙田秀夫

前田瓷昭・杉政和・宮崎正

\section{Cytological study on degeneration process of the cells in the epidemoid cyst well}

\author{
Tetsuo Yanagawa - Mitsunobu Sato - Kancmithu SHirasuna - Hideo Yoshida \\ Noriaki MaEda - Masakazu Sugi - Tadashi Mryasaki
}

舶

言

類表皮襄胞は外肧葉組織の嵌入によって生ずる裂胞で 口腔領域では主として口腔底にみられる。臨林的に本变 胞は弾力性のある柔らかい腫瘤として触れ，波動や正痛 を欠くのを特徵とするが，穿刺試験により黄白色の棦状 の物質を採取できることが爁別診断上，重要な手段とな

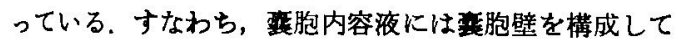
いる細胞からの分泌物ならびに細胞の变性物が含まれて いると考点られる．しかし，どのよらな機序により葆胞 壁細胞が变性過程を経て咅胞腔内に移行していくかとい ら点については非常に興味がるたれているが明らかにさ れていない.

われわれは最近，口腔底に生じた類表皮異胞を経験し たので，集胞壁細胞の変性過程について考えるため，亯 胞壁組織ならびに内容液中に存在する細胞について組織 培翊法を用いて検索した。

症

例

患 者: 36歳 男性.

初診: 昭和 52 年 12 月日日.

主 訴: 口空底の腫脹。

既往歴：特記すべき事項はなかった。

現病歴 : 約 4 年前より, 患者は口腔底の無痛性腫脹に 気ついていたが放置していたところ，畽脹は徐々に増大 傾向を示した。昭和52年 9 月ころより舌の運動障害に伴

大阪大学荤部口悺外科学第 1 講座（主任：宮崎正 数授)

The First Department of Oral and Maxillofacial Surgery, Osaka University, Dental School (Chief: Prof. Tadashi Miyasaki)

受付日：昭和53年 7 月 18 日

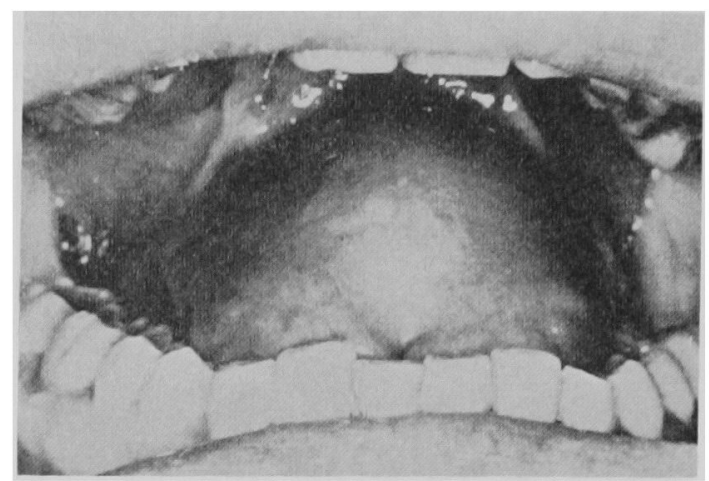

図 1 实験に使用した類表皮毫胞の臨床像

口腔底の巨大なる腫瘦により舌が誉上されている。

い発音障害於よび燕下障害を自覚するようになったた め，某㐘科医院を受彭したところ，本院当科を紹介され て来院した。

現 症 : 舌下口腔底中央部に小少手拳大の重脹があ り(図 1)，そのため，舌は後上方へ挙上され，舌の運動 障害, 軽度の発音障害が認められた。腫脹の表面はやや 赤味を带びた正常粘膜で招おわれていた，硬度は弾性 硬，可動性であり，王痛はなかった。試験穿刺により， 灰黄白色の彁状物を吸引した。オトガイ下部に軽度の腫 脹が認められたか，正痛はなかった。レントゲン検査の 結果, 畽溜の簤骨への侵暗像は全く認められなかった. 術前の臨床検査值に特記すべき異常はなかった。

処置および経過 : 類表皮黄胞の診断のもとに, 襄胞の 摘出は全身麻醉下にてロ腔内より行った，腫瘤が㬵頭蓋 付近にまで払大していたため，retrograde method によ り経奥插管を行った，舌下口腔底正中に絽切を加え，口 腔粘膜を豩離後，衰胞を摘出した，襄胞の範囲は前方で 下顎骨下縁，下方て顎舌骨筋上，後方は茎突舌筋の間に

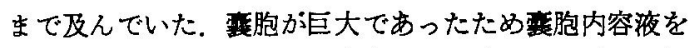
吸引，減圧することにより黄胞壁を一塊として摘出し得 


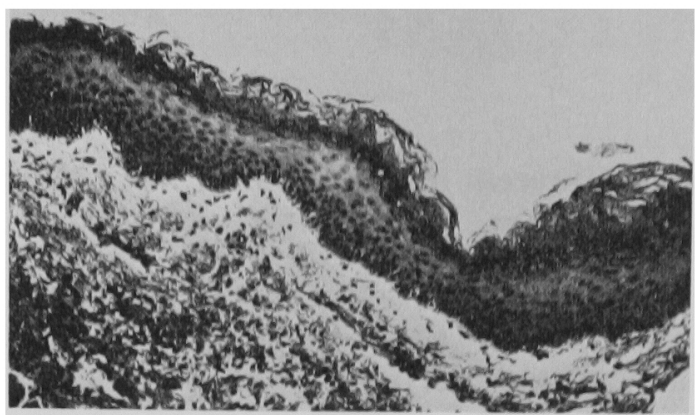

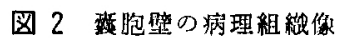

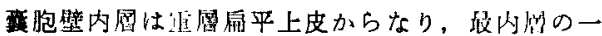

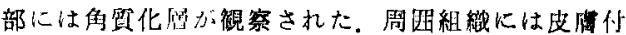
属器は㪊めない， $\times 100$

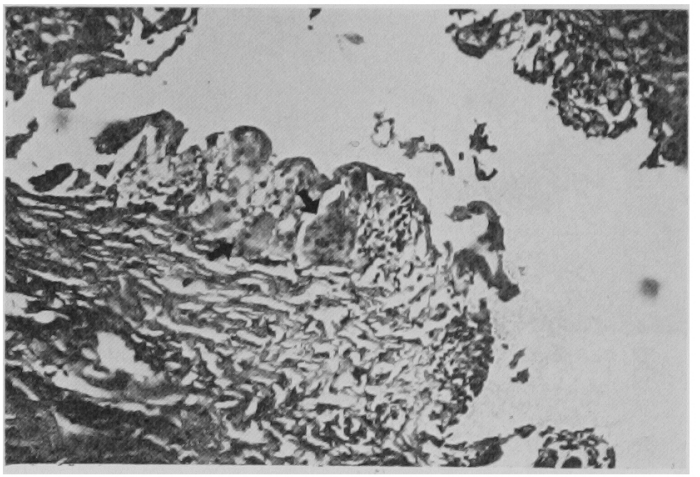

图3巨紐胞の出現せる高胞壁の病理組轼像

落胞内層は上皮の欠落せる部位があり，それに近 隣して巨細胞（矢印）の出現を号。，炎症珄細胞浸 潤はほとんど認めない。

た。

術後経過は局所的に，また全身的にも良好であり，術 前にみられた舌の運動障害は著明に改善し，発音も正常 に復した。

\section{摘出材料の検索法}

手術によって摘出された材料を以下のよ弓に検索し た。

組織学的観察法：摘出された䞔胞壁の数か所を10\%木 ルマリン溶液にて固定後，ェタノールにて脱水したのち パラフィン包埋した。切片をへマトキシリンーエオジン 染色したのら，観察した。

電子題微鏡学的観察法：䔶胞壁の1部を燐酸緩衝 $4 \%$

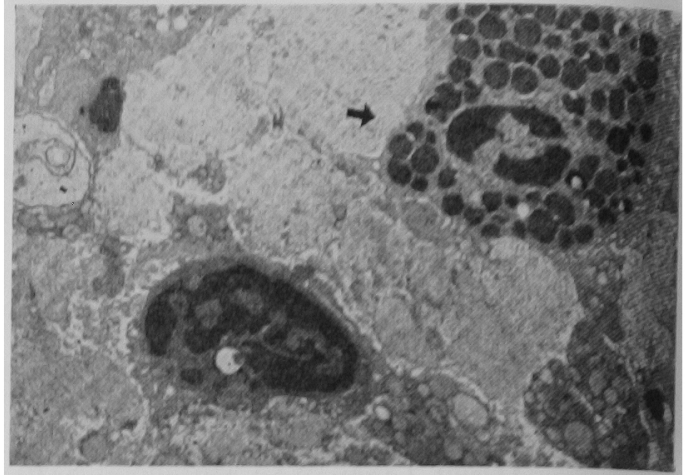

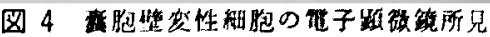

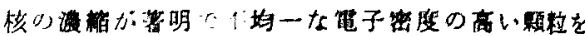

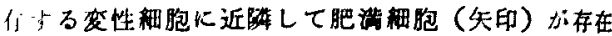
する. $\times 4,000$

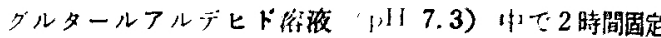

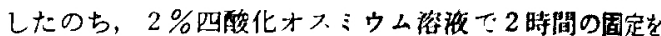

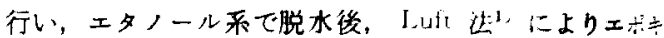
シ樹指包埋した，超薄切片を $4 \%$ 酢酸ウラニールならす

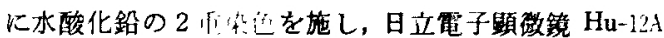
型にて観察した。

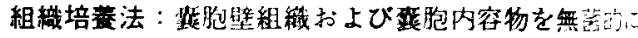

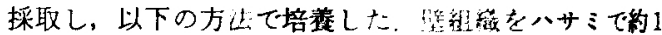

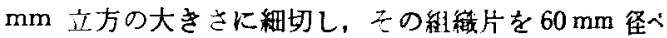
トリ血につれ，組穖片が゚トリ且底面に十分に付着した のち，增殖培港液を入れ，5\%炭酸ガス培善器中て $37^{\circ} \mathrm{C}$

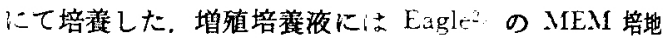

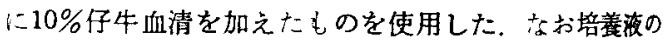
交换は䄪 4 日目ことに行った。約 3 週間挠，組絨片㲽录 より增殖してきた細胞を最終濃度 $0.08 \%$ トリフンおよ び $1.4 \%$ ンレンジミン四酢酸二ナトリゥム (EDTA) を含む脱 $\mathrm{Ca}^{-}, \mathrm{Mg}^{-}$リン酸縟衙液 ( $\left.\mathrm{pH} 7.2\right)$ にて細胞を 採取したのち，同様の增殖培意液にて培盖した，

整胞内容液的 $1 \mathrm{ml}$ を $6 \mathrm{ml}$ の堌殖培羡液にて混和し たものを $60 \mathrm{~mm}$ 径へトリ皿に入れ，上記と同様の方法て

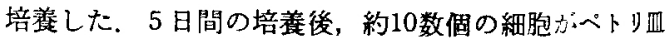
上に生着していることを確認したので，内容液中に含ま れている生細胞以外の物質を取り除くためにMEMて4

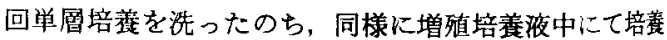
した，継代培盖は組織片より分離した細胞と同様に行っ た.

結果

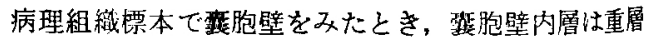
扁平上皮により扰扐われ，最内層の一部には角質化層が 锤察された（図 2)。また内層上皮の一部には著明な巨 細胞形成部がみられ，巨細胞には2〜5核を有する多核 細胞も存在していた（図3），さらに巨細胞形成部に移 


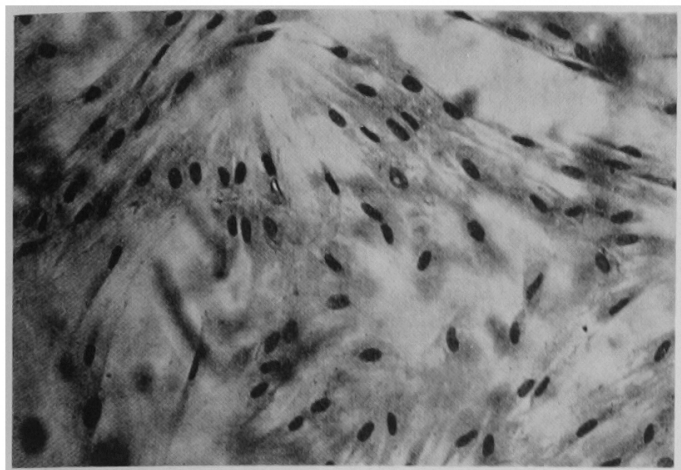

图 5 莫胞壁培相胞 2 代目 単一核を有する赤形形の梱胞で稩胞内に㙁基性の 顆粒を含む、 $\times 100$

行して上皮細胞の欠落像がみられたが，乙の周囲組織に

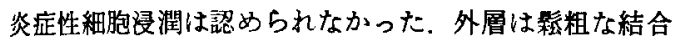
織からなり，一部に出血巣が認められた。なお，この層 に汗腺, 皮脂腺, 毛展などの皮膚付属器はみられなかっ た。

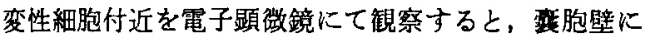
存在する変性細胞に著明な核濃縮像がみられた(图 4).

变性細胞の細胞質に系粒体と不场一な電子密度の低い顆 粒の存在が認められた。しかし，この細胞に典型的なリ ソソーム顆粒を諗めることはできなかった。変性細胞に 近位して肥満細胞を観察することが多かった（图 4).

咅胞内容物を試験穿刺により採取し，叙抹標本を作製 し，ギムザ染色を施したのちの観察結果は以下のごとく である内容物は好塩基性の不定形物よりなり、コレス テリン結晶を含んでいた。 また少数の核のない角質細胞 や虽離細胞残洫の存在む認められた.

霍胞壁細胞就よび内容液中に存在する生細胞の性質に ついて検索するため，組織培盖法により壁組織および内 容液からの細胞の分離を試みた，壁組織片をベトリ皿に 静置したのら，約 3 週間の培着後, 組織片辺縁からほと んど変性像を示さない細胞の增殖がみられた。

この細胞をギムザ染色したのら観察すると，多数の細 胞の細胞質あるいは細胞周辺に塩基性物質の存在がみら れた，この細胞を EDTAートリプシンにて採取し継代培 養を行った．初代のものでは汪とんと变性像を示さなか った(図 5)。これに対し，細胞継代数 3 代目の培羡細胞 で核周辺の細胞質に著明な顆粒および空胞形成がみら れるととすに細胞は巨細胞となった，また培着細胞の一 部に多核細胞あるいは核分裂像を示可細胞むみられた (图6).なお，これらの細胞は多核巨細胞の出現ととも に細胞增殖速度が低下し，細胞継代数 5 代目で死隇し た.

粟胞内容液より分離した細胞も壁組織片からの細胞と 同棣の所見を示した. 寸なわち, 内容液 $1 \mathrm{ml}$ を増殖培

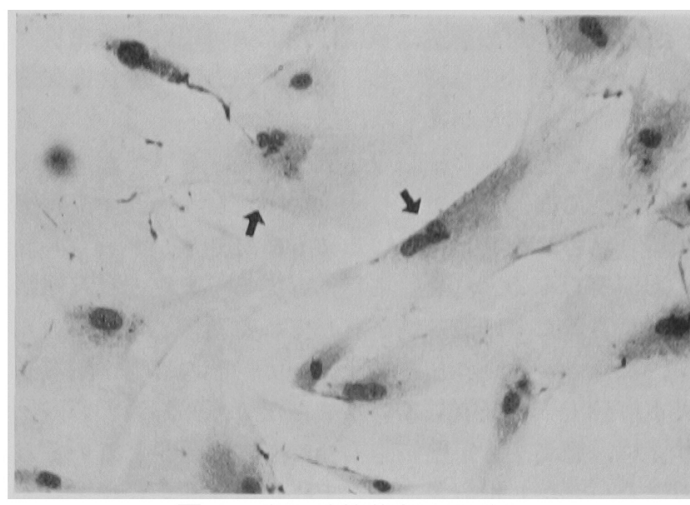

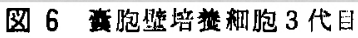

絊胞は巨耕胞となり，核む2 核あるいは多核の紐 胞 (矢印) が㑇められる。 $\times 100$

羡液に混和したものを $60 \mathrm{~mm}$ 径ぺトリ皿に入れ，5日 間培着したとき，約10数個の細胞がペトリ皿上に生着し ていることを確認したので，生細胞以外の他の物質を取 り除くために MEM で 4 回単層培榩を洗ったのら，細 胞を観察していたところ，培養初期では全く変性像を示 さない紡银形の細胞ですったが，継代培着すると核周囲 に空胞形成を示す多核巨細胞となった。なおこの細胞 は継代数 3 代目で死減した。

考察

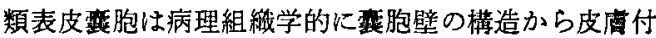
属器官を有する狭義の類皮鐢胞と表皮棈造の及の類表皮 泡胞さらに外肧葉，中肧葉，内胚葉の阫葉が混在してい

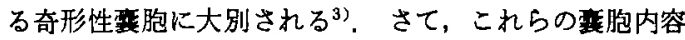

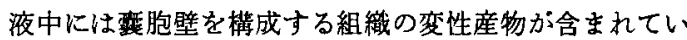
ることが強く示唆される、ゆえに，聅胞内容液と变胞壁 構造との間に何らかの関係を見い出し，これを臨床上診 断に応用するために内容液を生化学的に分析しようとす る試みがすでになされているい．しかしどのような機 序で壁細胞が变性という過程を経て裂胞内腔へ遊離され るのかという点については巽論のあるところである。

われわれは煖近，口腔底に生した典型的な類表皮潾胞 に遭遇した。 その組織像をみると繁胞壁の最内凰の一部 には著明な角化層がみられた。ささらに一部の内層組織に 著明な巨細胞形成部かみられ，この部から移行して上皮 細胞層の欠落像がみられた。 上記の所見は壁細胞が変性 し漹胞内に移行する過程には通常の皮虚組織にみられる 角質化变性といら道のほかに椎胞壁内層組織での巨細胞 変性も重要な過程であることを示唆している.

上記の巨細胞変性はコレステリン結晶のような異物に 対する貝喰作用によって生ずると，一般的に考えられて いる5 事実すでに示されている所見，すなわち関節膑 内で，尿酸塩を macrophage が取り込む像6)，あるいは 


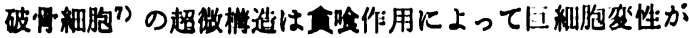
生しることを示睃している。この考え方は敒復性肉芽盾

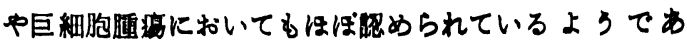
る. しかしそれらの細胞の超微棈造をみる る食細胞の標造とは與なり lysosome るみられデ，細胞 小器官はむしろ発连しているよろに思える。

本症例をみると，变性細胞に近接して多数の肥满細胞 か部察された，肥满細胞が有している顆粒にはヒスタミ ン, セロトニン ${ }^{11}$ に加えて lysosome 内の醉案に蛽似し た水解醉莱 ${ }^{12)}$ を保有していることがよく知られている.

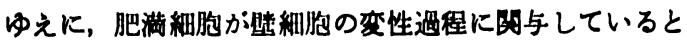
考えた。しかし組械像において巨細胞变性が存在する部

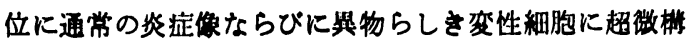
造においてもいわゆる lysosomal 変性像を示さなかっ た. 以上の結果より巨細胞变性の機序として単なる具喰 作用を考えることはできなかった．

われわれは樭胞壁を構成している細胞ならびに烡胞内 容液中に制莬されている細胞の性質を娭索するためにそ れぞれから細胞を in vitroに分雄した，分離された細 胞はともに培養初期においては变性像を示さない細胞で あったか，継代培善すると細胞は徐々に巨大化し，多核 細胞ならびに核分裂像を示するのる出現した，その後， 細胞增殖速度は著明に低下し，壁組織由来の細胞は継代 数 5 代目で，内容液からの細胞は継代数 3 代目で死娍し た。すなわち，变胞を粠成している細胞からほかの因子 を取り除くため，in vitro に分離された細胞が上記の所 見を示したことは，昙胞を權成している細胞自体に多核 巨細胞変性を起こし死娍していく，なにか㯰命的な機㭗 が㑬いていることを示唆しているかもしれない. 上記の 細胞かいかなる機序により多核巨細胞が出現したのかは 現在不明である，多核巨細胞の成因として，一般的に細 胞の融合によって生ずると考えられている.すでにある 種のウイルス ${ }^{13)}$, ポリエチレングリコールあるいはレソ レシチン14)などが細胞骶合能を有することが明らかとな っている.しかし，われわれが観察した培養細胞におい て、たしかに細胞融合が生じたと思われる所見は得られ なかった，むしろ，噥胞由来の培養細胞は著明な核分裂 像を示したにもかかわらず細胞の增殖能が著明に低下し たことから，細胞は核分裂を通常に行う能力を保有する にひかかわらす細胞分裂をなにかの因子によって抑えら れていたように思えた。 たとえばカビから抽出されるサ イトカラシン $\mathrm{B}^{15)}$ という物質は細胞の核分裂を阻止しな いけれどす細胞分裂を完全に抑えることが知られてい る. また低瀑度のコルセマイドの長期処理によっても同 様の現象か起こるといわれている16).

われわれは現在，䓙胞壁を構成している細胞あるいは 内容液中に上記の現象を引き起こす要因について検索を 行っている.
結

\section{会}

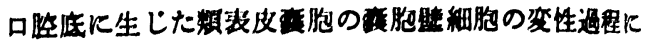
ついて湌第を行い，以下の綃果を得た。

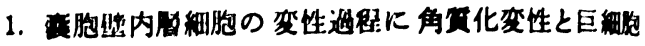

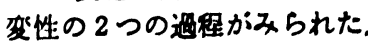

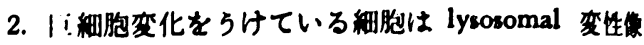

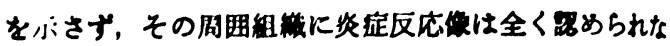
かった.

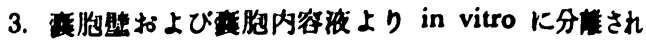
た細胞は，培誉初期において变性像を示さなかったにい

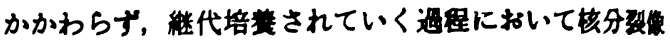
あるいは多核を有する巨細胞に变化し，死泣した。

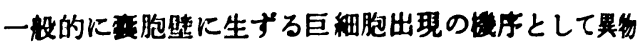
などに対する全喰作用によって生ずると考えられてきた

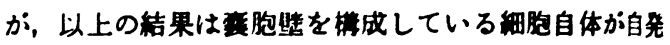

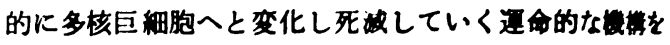

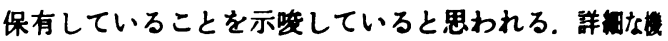

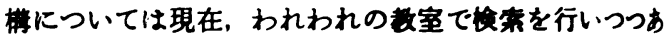
ろ.

\section{引用文嗝}

1) Luft, J.H.: Improvements in eponxy resin embedding methods. J Biophy Bioshem Cytol 9: 4091961.

2) Eagle, H.: Amino acid metabolism in mammalian cell culutures. Science 130: 4321959.

3) Meyer, I.: Dermoid cysts (dermids) of the floor of the mouth. OS OM OP 8: 1149 1955.

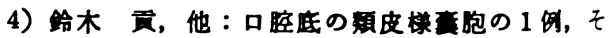

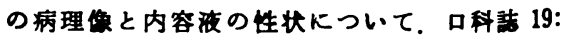
6831970.

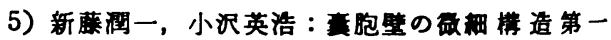

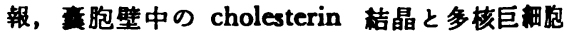
について. 口科誌 23: 4311974.

6) McCarthy, D.J.: Phagocytosis of urate crystals in gouty synovial fluid. Am J Med Sci 243: 2881962.

7) Hancox, N.M., and Boothroyd, B.: Ultrastructure of bone formation and resorption. InClark, J.M.(editor): Modern Trends in Orthopaedics, vol. 4, Science of Fractures, London, 1963, Butterworth \& Co, Ltd, p 26.

8) Sapp, J.P.: An ultrastructual study of Nuclear and Centriolar Configurations in Multinucleated Giant cell lesion. OS OM OP 28: 713.

9) Einsenstein, R.: Giant cell tumor of Tendon sheath. J Bone \& Joint Surg 50: 4761968.

10) Hagen, P., Barnnett, R.J. and Lee, F.L: 
Biochemical and electronmicroscopic study of particles isolated from mastocytoma cells. J Pharmacol Exp Ther 126: 911959.

11) Von orden, L.S. III, Vugman, I.m, Bensch, K.G., and Giarman, N.J.: Biochemical, histochemical and electron-microscopic studies of 5-hydroxytryptamine in neoplastic mast cells. J Pharmacol Exp Ther 158: 195 1967.

12) Okada, Y.: Analysis of giant polynuclear cell formation caused by HVJ virus from Ehrlich's ascites tumor cells. Microscopic observation of giant polynuclear cell formation. Exp Cell Res 26: 981962.

13) Poole, A.R., Howell, J.I. and Lucy, J.A.: Lysolecthin and cell fusion. Nature 227: 810 1970.

14) Carters. B.: Effects of cytochalasins of Mammalian cells. Nature 213: 2611967.

15) Stubbefield, E.: Cytogenetics of cells in culture. (ed RJC Harris) Academic Press, New York 1964, p 223. 